\title{
ANALISIS RASIO KEUANGAN DAERAH DALAM MEMPENGARUHI BELANJA MODAL PUBLIK BAGI PERTUMBUHAN EKONOMI
}

\author{
Aula Ahmad Hafidh \\ Universitas Negeri Yogyakarta \\ e-mail: aulaghina@gmail.com
}

\begin{abstract}
Abstrak: Analisis Rasio Keuangan Daerah dalam Mempengaruhi Belanja Modal Publik bagi Pertumbuhan Ekonomi. Penelitian ini bertujuan untuk mengetahui pengaruh rasio keuangan daerah terhadap belanja modal publik bagi pertumbuhan ekonomi. Penelitian ini merupakan penelitian deskriptif kuantitatif. Penelitian menggunakan data APBD dan PDRB Kota dan Kabupaten di DIY periode 2006-2011. Hasilnya menunjukkan bahwa semua daerah masih mempunyai tingkat kemandirian daerah (KD) yang sangat rendah. Tingkat efisiensi daerah (EFD) menunjukkan nilai yang kurang baik. Variabel efektivitas daerah menunjukkan rasio yang cukup efektif karena semua daerah mampu melampaui target penerimaan yang telah ditetapkan. Penelitian ini juga menemukan bahwa ketiga rasio keuangan daerah menunjukkan hasil yang positif dan signifikan, akan tetapi $\mathrm{R}^{2}$ hanya sebesar 0,38 . Artinya kinerja keuangan yang diproksi dari PAD tidak dapat mempengaruhi belanja modal publik. Belanja modal mempengaruhi PDRB secara positif dan signifikan. Jadi, model kinerja daerah yang dinyatakan dalam rasio keuangan daerah tersebut hanya mampu menerangkan perubahan pada variabel PDRB sebesar 35 persen.
\end{abstract}

Kata kunci: Rasio Keuangan Daerah, Belanja Modal, Pertumbuhan Ekonomi

\begin{abstract}
Analysis on Regional Financial Ratios effect on the Public Capital Expenditure for Economic Growth. This study aims to determine the effect of the ratio of capital expenditures to finance public areas, for economic growth. The study used data of APBD and PDRB of the city and regency in the DIY period 2006-2011. The results showed that all areas still have a degree of independence of the region (KD) which is very low. Regional efficiency levels (EFD) shows poor value. Efficacy variable local indicates that the ratio is quite effective because all regions are able to exceed the income target has been set. The study also found that the three regional financial ratios showed positive results and significant but the R2 value of only 0.38 . That is financial performance proxied from the PAD can not affect the public capital expenditures. Capital expenditures affect PDRB positively, and significantly. Thus, the performance of the local model which is expressed in the area of financial ratios are only able to explain changes in the variables GDP by 35 percent.
\end{abstract}

Keywords: Regional Financial Ratios, Capital Expenditures, Economic Growth

\section{PENDAHULUAN}

Reformasi di berbagai bidang yang berlangsung di Indonesia telah membawa perubahan terhadap sistem politik, sosial, kemasyarakatan serta ekonomi sehingga menimbulkan tuntutan yang beragam terhadap pengelolaan pemerintahan yang baik. Salah satu agenda reformasi yaitu adanya otonomi daerah dan sistem pengelolaan keuangan daerah. Hal tersebut ditandai dengan diterbitkannya Undang-Undang No. 22 Tahun 1999 tentang Pemerintahan Daerah, Undang-Undang No. 25 Tahun 1999 tentang Perimbangan Keuangan antara Pemerintah Pusat dan Daerah, Undang-Undang Nomor 32 Tahun 2004 tentang Pemerintahan Daerah dan Undang-Undang Nomor 33 Tahun 2004 tentang Perimbangan Keuangan 
antara Pemerintah Pusat dan Pemerintah Daerah, Peraturan Pemerintah Nomor 58 Tahun 2005 tentang Pengelolaan Keuangan Daerah. Undang-undang dan Peraturan Pemerintah yang telah disebutkan di atas membuka peluang yang luas bagi daerah untuk mengembangkan dan membangun daerahnya sesuai dengan kebutuhan dan prioritasnya masing-masing. Pembaharuan subjek pengelolaan keuangan daerah yang ada dalam Undang-undang Nomor 32 Tahun 2004 adalah ekonomis, efektifitas, dan efisiensi pengelolaan keuangan daerah baik dari sisi pendapatan maupun belanja. Inti dari pembaharuan tersebut adalah untuk mempertajam esensi pengelolaan keuangan daerah dalam sistem penyelenggaraan pemerintahan daerah yang menyangkut penjabaran terhadap hak dan kewajiban daerah dalam pengelolaan keuangan publik. Hal ini akan mempengaruhi prinsip pengelolaan, mekanisme penyusunan, pelaksanaan dan penatausahaan, pengendalian dan pengawasan, serta pertanggungjawaban Keuangan Daerah.

Sebagai operasionalnya maka Menteri Dalam Negeri telah mengeluarkan Peraturan Menteri Dalam Negeri No. 59, Tahun 2007 tentang Pengelolaan Keuangan Daerah. Otonomi daerah menurut Undang-undang Nomor 32 tahun 2004 merupakan hak, wewenang, dan kewajiban daerah otonom untuk mengatur dan mengurus sendiri urusan pemerintahan dan kepentingan masyarakat setempat sesuai dengan peraturan perundang-undangan. Pemberian otonomi daerah diharapkan dapat meningkatkan efisiensi, efektivitas, dan akuntabilitas sektor publik di Indonesia. Dengan otonomi, daerah dituntut untuk mencari alternatif sumber pembiayaan pembangunan tanpa mengurangi harapan masih adanya bantuan dan bagian (sharing) dari Pemerintah Pusat dan menggunakan dana publik sesuai dengan prioritas dan aspirasi masyarakat (Mardiasmo, 2002).

Pendelegasian wewenang kepada Pemerintah Daerah (Pemda) tersebut disertai dengan penyerahan dan pengalihan penda- naan, sarana dan prasarana, serta Sumber Daya Manusia (SDM). Pendanaan kewenangan yang diserahkan tersebut dapat dilakukan dengan dua cara yaitu pendayagunaan potensi keuangan daerah dan mekanisme perimbangan keuangan antara pemerintah pusat-daerah dan antar daerah (Mardiasmo, 2002). Pendanaan pelaksanaan kewenangan tersebut memerlukan pengelolaan keuangan yang efisien dan efektif (Kawedar, 2008). Dalam pengelolaan keuangan harus mengacu kepada Peraturan Pemerintah No. 58 tahun 2005 tentang Pengelolaan Keuangan Daerah dan Permendagri No.13 tahun 2006 yang telah diperbaharui dengan Permendagri No. 59 Tahun 2007 tentang pedoman pengelolaan keuangan daerah, mulai dari penyusunan anggaran, pelaksanaan anggaran sampai pertanggungjawaban penggunaan anggaran daerah. Sedangkan penyajian laporan keuangan pemerintah daerah harus mengacu kepada Peraturan Pemerintah No.24 tahun 2005 tentang standar akuntansi pemerintah.

Tranparansi atau keterbukaan yang sangat diperlukan oleh publik adalah akuntanbilitas pengelolaan keuangan pemerintah daerah. Sedangkan akuntabilitas atas pengelolaan keuangan daerah harus didukung oleh sistem ekonomi pemerintah yang mampu menyediakan informasi untuk tujuan pertanggungjawaban (stewardship and accountability), mengontrol dan pengawasan atau pengendalian manajemen pemerintah daerah. Akuntabilitas menjadi sangat penting karena akuntabilitas merupakan salah satu elemen manajemen keuangan pemerintah untuk mengontrol kebijakan pengelolaan keuangan, di samping konsep value for money, kejujuran, transparansi dan pengendalian.

Pemerintah daerah sebagai pihak yang diserahi tugas menjalankan roda pemerintahan, pembangunan dan pelayanan masyarakat wajib menyampaikan laporan pertanggungjawaban keuangan daerahnya untuk dinilai apakah pemerintah daerah berhasil menjalankan tugasnya dengan baik atau tidak. Selain satu alat untuk menganalisis 
kinerja pemerintah daerah dalam mengelola keuangan daerahnya adalah dengan menggunakan analisis rasio keuangan terhadap APBD yang telah ditetapkan dan dilaksanakan, yang diharapkan akan memberikan informasi yang lebih rinci atas hasil interprestasi mengenai prestasi yang dicapai dan keadaan keuangan daerah. Analisis rasio keuangan sebagai sumber informasi keuangan sangat bermanfaat apabila angka-angka rasio daerah tersebut dibandingkan dari tahun ke tahun, dengan membandingkan angka rasio untuk beberapa periode akan dapat mengetahui semakin efisien tidaknya dalam mengelola keuangan daerah.

Pengelolaan keuangan daerah mencakup aktivitas; perencanaan, pelaksanaan, pengawasan, pengendalian, pelaporan dan evaluasi (PP. No. 58 tahun 2005). Pengawasan dan pengendalian dalam pengelolaan keuangan daerah dimaksudkan agar setiap rupiah yang dibelanjakan pemerintah berdampak terhadap kepentingan dan kebutuhan publik dan dapat dipertanggungjawabkan kepada publik (Arsyad, 2004). Pengelolaan keuangan daerah yang dapat dipertanggungjawabkan ditandai dengan hasil laporan keuangan yang transparan dan akuntabel. Transformasi paradigma dalam hal ini terletak pada aspek akuntabilitas Pemerintah Daerah dalam rangka mengelola sumber-sumber ekonomi yang semula bersifat akuntabilitas vertikal (kepada Pemerintah) menjadi akuntabilitas horizontal kepada masyarakat di daerah (Mardiasmo, 2002). Tujuan utama penyelenggaraan otonomi daerah adalah untuk meningkatkan pelayanan publik (publik service) dan memajukan perekonomian daerah. Kemandirian keuangan daerah menunjukkan kemampuan pemerintah daerah dalam membiayai sendiri kegiatan pemerintahan, pembangunan dan pelayanan kepada masyarakat yang telah membayar pajak dan retribusi sebagai sumber pendapatan yang diperlukan daerah.

Rasio Kemandirian Daerah mencerminkan keadaan otonomi suatu daerah yang diukur dengan besarnya PAD terhadap jumlah total pendapatan daerah. Sehingga memunculkan permasalahan suatu daerah yang dikatakan mandiri dapat meningkatkan jumlah belanja modal untuk pelayanan publik. Hal ini senada dengan penelitian Vegasari (2010) bahwa Rasio Kemandirian Daerah tahun lalu berpengaruh signifikan terhadap belanja modal tahun berikutnya. Untuk Rasio Efektivitas, diukur dengan cara membandingkan jumlah realisasi PAD dan target PAD yang dihitung berdasarkan alokasi PAD tahun bersangkutan, sehingga suatu daerah dapat dikatakan efektif apabila jumlah realisasi pendapatan lebih tinggi daripada target yang ditetapkan. Penelitian yang dilakukan Vegasari (2011) menerangkan bahwa rasio efektivitas pemerintah daerah tahun sebelumnya tidak berpengaruh terhadap belanja modal tahun berjalan. Sehingga memunculkan suatu dilema tentang moral hazard pemerintah daerah tentang penggunaan PAD. Sedangkan untuk Rasio Efisiensi Daerah, diukur dengan cara membandingkan total pengeluaran daerah dengan total pendapatan daerah. Suatu daerah dikatakan efisien jika pengeluaran daerah kecil dan total pendapatannya tinggi. Hal ini senada dengan penelitian Vegasari (2010) bahwa Rasio Efisiensi Keuangan Daerah tahun lalu berpengaruh signifikan terhadap belanja modal tahun berikutnya. Hal ini juga memunculkan pertanyaan, daerah yang dikatakan efisien secara keuangan akan dapat mempengaruhi jumlah belanja modal, padahal efisiensi tidak memerlukan jumlah pengeluaran yang besar atau dalam hal ini disebut belanja.

Moral hazard pemerintah daerah juga dipertanyakan dalam hal ini tentang kelanjutan penggunaan penerimaan daerah khususnya PAD. PAD yang tinggi mencerminkan keuangan daerah yang maju, sehingga pengalokasian untuk belanja modal juga dipertanyakan. Daerah yang maju cenderung mempertahankan struktur belanja menjadi belanja pemeliharaan (Khusaeni,2006). Tidak serta merta untuk belanja modal saja. Pergeseran pola belanja ini yang menjadi permasalahan krusial di pemerintah daerah mengingat sejauh mana pentingnya 
diadakan pendanaan untuk belanja modal. Motivasi yang melandasi penelitian ini antara lain adanya pergeseran pola belanja dalam pemerintah daerah khususnya belanja modal. Hal ini memicu permasalahan tentang sejauh mana besarnya PAD mempengaruhi pola belanja pemerintah daerah khususnya belanja modal untuk pelayanan publik. Beberapa studi empiris yang telah dilakukan menunjukkan bahwa upaya pemerintah daerah untuk meningkatkan penerimaan daerah telah menimbulkan distorsi pasar dan high cost economy (Saad, 2000). Sehingga diasumsikan jika belanja modal untuk pelayanan publik meningkat maka akan meningkatkan pertumbuhan ekonomi tahun berikutnya. Selain itu, upaya-upaya yang dilakukan pemerintah daerah untuk meningkatkan penerimaan daerah kurang diikuti upaya untuk meningkatkan pelayanan publik (Abdullah dan Halim, 2006).

Berdasarkan uraian latar belakang di atas, untuk meningkatkan pengalokasian anggaran ke sektor belanja modal diperlukan pengetahuan mengenai komponenkomponen apa saja yang berpengaruh positif terhadap jumlah alokasi untuk belanja modal pelayanan publik. Dengan demikian, penelitian ini bertujuan untuk mengetahui pengaruh kemandirian daerah, efektivitas keuangan daerah, efisiensi keuangan daerah dapat mempengaruhi belanja modal untuk pelayanan publik dan selanjutnya mengetahui belanja modal untuk pelayanan publik dapat mempengaruhi pertumbuhan ekonomi.

Konsekuensi logis pelaksanaan otonomi daerah berdasarkan UU No. 22 tahun 1999 dan UU No. 25 tahun 1999 menyebabkan perubahan dalam manajemen keuangan daerah. Perubahan tersebut antara lain adalah perlunya dilakukan reformasi anggaran. Aspek utama reformasi anggaran adalah perubahan dari traditional budget ke performance budget (Khusaeni, 2006). Anggaran tradisional merupakan pendekatan yang paling banyak digunakan di negara berkembang dewasa ini. Terdapat dua ciri utama dalam pendekatan ini, yaitu: (a) cara penyusunan anggaran yang didasarkan atas pendekatan incrementalism dan (b) struktur dan susunan anggaran yang bersifat lineitem. Masalah utama anggaran tradisional adalah terkait dengan tidak adanya perhatian terhadap konsep value for money. Konsep ekonomi, efisiensi dan efektivitas seringkali tidak dijadikan pertimbangan dalam penyusunan anggaran tradisional. Dengan tidak adanya perhatian terhadap konsep value for money ini, seringkali pada akhir tahun anggaran terjadi kelebihan anggaran yang pengalokasiannya kemudian dipaksakan pada aktivitas-aktivitas yang sebenarnya kurang penting untuk dilaksanakan. Reformasi sektor publik yang salah satunya ditandai dengan munculnya era $\mathrm{New}$ Publik Management telah mendorong usaha untuk mengembangkan pendekatan yang

Tabel 1. Perbedaan Anggaran Tradisional dan Anggaran New Publik Management

\begin{tabular}{ll}
\hline Anggaran Tradisional & Anggaran New Publik Management \\
\hline Sentralistik & Desentralisasi dan development management \\
Berorientasi pada input & $\begin{array}{l}\text { Berorientasi pada input, output dan outcome (value for } \\
\text { money) }\end{array}$ \\
Tidak terkait dengan perencanaan & $\begin{array}{l}\text { Utuh dan komprehensif dengan perencanaan jangka } \\
\text { panjang }\end{array}$ \\
jangka panjang & Berdasarkan sasaran dan target kerja \\
Line item dan incrementalism & Cross department \\
Aturan klasik vote accounting & Zero base budgeting, planning programming budgeting \\
& system \\
Prinsip anggaran bruto & Sistematik dan rasional \\
Bersifat tahunan & Bottom-up budgeting \\
\hline
\end{tabular}

Sumber : Artikel OTDA tahun I-4 2002 
lebih sistematis dalam perencanaan anggaran sektor publik. Seiring dengan perkembangan tersebut, muncul beberapa teknik penganggaran sektor publik, misalnya adalah teknik anggaran kinerja (performance budgeting), Zero Based Budgeting (ZBB), dan Planning, Programming, and Budgeting System (PPBS).

Semakin meningkatnya kegiatan pembangunan di daerah, semakin besar pula kebutuhan akan dana yang harus dihimpun oleh Pemerintah Daerah, kebutuhan dana tersebut tidak dapat sepenuhnya disediakan oleh dana yang bersumber dari pemerintah daerah sendiri (Hirawan, 1986). Dengan demikian maka perlu mengetahui apakah suatu daerah itu mampu untuk mengatur dan mengurus rumah tangganya sendiri, maka kita harus mengetahui keadaan kemampuan keuangan daerah.

Tuntutan yang tinggi terhadap kinerja dan akuntabilitas kinerja pemerintah daerah ini berjuang pada kebutuhan pengukuran kinerja pemerintah daerah. Pengukuran kinerja pemerintah daerah mempunyai banyak tujuan. Tujuan tersebut paling tidak untuk meningkatkan kinerja dan meningkatkan akuntabilitas pemerintah daerah. Untuk itu pemerintah daerah dituntut untuk mampu membangun ukuran kinerja yang baik. Ukuran kinerja yang disusun tidak dapat hanya dengan menggunakan satu ukuran saja, oleh karena itu perlu ukuran yang berbeda untuk tujuan yang berbeda pula. Ukuran kinerja mempengaruhi ketergantungan antar unit kerja yang ada dalam satu unit kerja (Mardiasmo, 2002).

Analisis keuangan adalah suatu usaha untuk mengidentifikasi ciri-ciri keuangan berdasarkan laporan keuangan yang tersedia. Analisis rasio keuangan terhadap anggaran pendapatan dan belanja daerah (APBD) dilakukan dengan cara membandingkan hasil yang dicapai oleh suatu daerah dari satu periode terhadap periode sebelumnya, sehingga dapat diketahui bagaimana kecenderungan yang terjadi. penyajian laporan keuangan pemerintah daerah mempunyai keterbatasan serta sifat dan cakupan yang berbeda. Penyusunan anggaran pendapatan dan belanja daerah (APBD) selama ini berdasarkan asas keseimbangan, di mana masing-masing kelompok pendapatan belanja besarnya dihitung dengan meningkat sejumlah persentase tertentu (berdasar tingkat inflasi), sehingga mengabaikan adanya resiko keuangan dalam anggaran pendapat dan belanja daerah (APBD) (Halim, 2001).

Pendapatan Asli Daerah (PAD) dapat dialokasikan untuk kegiatan pelayanan kepada publik yang merupakan salah satu harapan masyarakat kepada pemerintah di dalam era desentralisasi fiskal ini. Peningkatan pelayanan publik yang dimaksud salah satunya adalah dengan pemberian proporsi belanja modal yang lebih besar. Belanja modal (BM) merupakan belanja yang dipergunakan untuk jangka waktu lebih dari satu tahun atau disebut jangka panjang untuk mendapatkan aset tetap pemerintah daerah, yaitu : peralatan, bangunan, infrastruktur dan harta tetap lainnya dengan cara membeli yang umumnya dilakukan dengan proses lelang atau tender yang cukup rumit (Abdullah dan Halim, 2006).

Belanja modal yang dilakukan oleh pemerintah daerah juga digunakan di antaranya untuk pembangunan dan perbaikan infrastruktur di dalam sektor pendidikan, kesehatan dan transportasi sehingga masyarakat pun turut menikmati manfaat dari pembangunan daerah. Tersedianya infrastruktur yang baik diharapkan dapat menciptakan efisiensi dan efektifitas di berbagai sektor tersebut, produktivitas masyarakat pun menjadi semakin tinggi dan pada akhirnya terjadi peningkatan pertumbuhan ekonomi. Tetapi otonomi daerah yang saat ini sudah berjalan di tiap kabupaten dan kota di Indonesia tetap menimbulkan persoalan baru, karena ternyata potensi pemerintah daerah yang satu dengan daerah yang lainnya masih sangat beragam. Hal ini disebabkan oleh kesiapan dari masing-masing daerah yang berbeda-beda dalam pelaksanaan otonomi daerah. Perbedaan yang terjadi ini akan menghasilkan pertumbuhan 
ekonomi yang beragam pula. Hal ini disebabkan karena dengan adanya peningkatan PAD, maka dana yang dimiliki oleh pemerintah daerah tersebut akan lebih tinggi, sehingga pemerintah daerah akan berinisiatif untuk lebih menggali potensi-potensi daerah dan akhirnya akan meningkatkan pertumbuhan ekonomi (Harianto dan Adi, 2007).

\section{METODE}

Penelitian ini merupakan penelitian deskriptif kuantitatif. Pendekatan yang diambil adalah pendekatan kuantitatif. Pengambilan keputusan tersebut didasarkan pada hasil analisis yang dilakukan berdasarkan kajian teori dan ekonometrika. Jenis data yang digunakan dalam penelitian ini adalah data sekunder berupa data APBD dan PDRB Kota dan Kabupaten di DIY yang terdiri dari 1 Kota dan 4 Kabupaten, yakni Kota Yogyakarta, Kabupaten Bantul, Kabupaten Gunungkidul, Kabupaten Kulonprogo dan Kabupaten Sleman. Data yang dianalisis dalam penelitian ini adalah data sekunder yaitu data yang telah diolah lebih lanjut dan disajikan oleh pihak lain. Penelitian ini menggunakan pooled data yaitu kombinasi antara data time series dengan data cross section selama periode tahun 2001 sampai dengan 2010. Populasi dalam penelitian ini adalah Pemerintah Kabupaten /Kota di DIY terdiri dari 4 Kabupaten dan 1 Kota. Penulis dalam penelitian mengambil seluruh populasi dikarenakan tersedianya seluruh data. Jumlah Kabupaten/Kota menyampaikan Laporan Realisasi APBD Tahun 2001 hingga 2010 kepada Dirjen Perimbangan Keuangan Pemerintah Daerah sebanyak 5 Kabupaten/ Kota di DIY sehingga diperoleh 50 unit. Dalam penelitian ini terdapat Empat (4) variabel independen, yaitu variabel Kemandirian Daerah (KD), Efektivitas Keuangan Daerah (EKD) dan Efisiensi Keuangan Daerah (FKD). Variabel dependen adalah Belanja Modal (BM) dan Pertumbuhan Ekonomi (PDB).

Model fungsi yang akan digunakan untuk mengetahui pengaruh rasio keuangan terhadap belanja modal pemerintah daerah yaitu:

\section{$\mathrm{BM}=\mathrm{f}(\mathrm{KD}, \mathrm{EKD}, \mathrm{EFKD})$ \\ BMit $=\beta 0+\beta 1$ KDit $+\beta 2$ EKDit $+\beta 3$ EFKDit+ Uit}

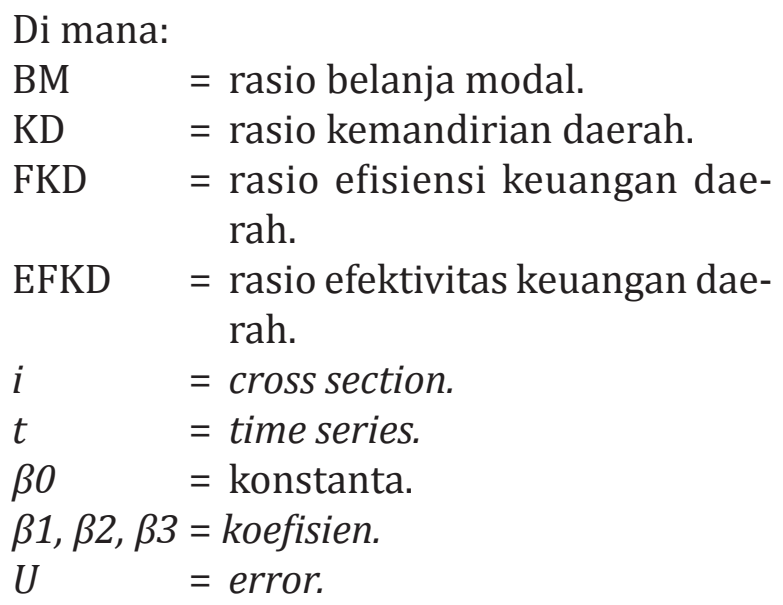

Hasil estimasi tersebut selanjutnya diregresikan secara sederhana untuk mengetahui pengaruh belanja modal terhadap pertumbuhan ekonomi daerah

\section{PDRB = $\mathbf{f}(B M)$ \\ PDRBit $=\beta 0+\beta 1 B M i t+e i t$}

Menurut Gujarati (2003), sebuah model penelitian secara teoretis akan menghasilkan nilai parameter penduga yang tepat bila memenuhi uji asumsi klasik dalam regresi, yaitu meliputi deteksi normalitas data, deteksi multikolinearitas, deteksi heteroskedastisitas, dan deteksi autokorelasi.

\section{HASIL DAN PEMBAHASAN}

Data yang digunakan dalam penelitian ini adalah data panel yang merupakan gabungan antara data time series dan data cross section. Dalam utama yang dipakai adalah data pendapatan asli daerah (PAD), Total Pendapatan, belanja modal dan PDRB. Data tersebut dicarikan rasionya dengan formula yang sudah ada untuk melihat pengaruhnya terhadap belanja modal. Data terdiri dari 4 kabupaten dan 1 kota di DIY dari tahun 2006 sampai dengan 2011.

Pendapatan asli daerah seluruh daerah di DIY masih menunjukkan hasil yang kurang baik karena masih sangat kecil jika 
dibandingkan dengan pendapatan totalnya. Pendapatan masih dominan berasal dari alokasi dana dari DAU pemerintah pusat.

PAD yang paling besar adalah Kota Yogyakarta dibandingkan dengan wilayah lainnya. Sedangkan Gunungkidul mempunyai
PAD paling kecil. Setiap tahunnya setiap daerah mampu meningkatkan PADnya seiring dengan meningkatnya PDRB. Ketiga daerah yaitu Bantul, Sleman dan Yogyakarta mampu meningkatkan PAD lebih dari 100 persen dalam kurun waktu 6 tahun.

Tabel 2. Pendapatan Asli Daerah Kab/Kota di DIY 2006-2011 (dalam juta rupiah)

\begin{tabular}{lcccccc}
\hline & 2006 & 2007 & 2008 & 2009 & 2010 & 2011 \\
\hline Kab. Bantul & 39,330 & 42,777 & 48,429 & 65,992 & 81,637 & 106,885 \\
Kab. Gunung Kidul & 25,486 & 27,474 & 25,240 & 31,951 & 42,542 & 41,985 \\
Kab. Kulon Progo & 28,892 & 33,130 & 36,189 & 41,938 & 48,281 & 49,588 \\
Kab. Sleman & 86,472 & 100,374 & 97,907 & 117,315 & 163,056 & 198,720 \\
Kota Yogyakarta & 91,627 & 100,374 & 119,301 & 135,107 & 179,424 & 202,261 \\
\hline
\end{tabular}

Tabel 3. Kriteria Kemandirian Daerah

\begin{tabular}{lcc}
\hline Daerah & Kemandirian & Kriteria \\
\hline Kab. Bantul & 7,67 Persen & Rendah Sekali \\
Kab. Gunung Kidul & 4,73 Persen & Rendah Sekali \\
Kab. Kulon Progo & 7,10 Persen & Rendah Sekali \\
Kab. Sleman & 14,88 Persen & Rendah Sekali \\
Kota Yogyakarta & 20 Persen & Rendah Sekali \\
\hline
\end{tabular}

Meskipun secara kriteria, semua daerah mempunyai hasil rendah sekali karena nilainya dibawah 25 persen, Kota Yogyakarta mempunyai kemampuan menghasilkan PAD mencapai 20 persen secara relatif terhadap total pendapatan. Sedangkan Kabupaten Gunungkidul hanya mencapai 4 persen saja, hal ini menunjukkan sangat membutuhkan dan mengandalkan DAU dalam melaksanakan pembangunannya.

Data yang berbeda ditunjukkan dalam alokasi belanja modal untuk kepentingan publik. Kabupaten Gunungkidul mempunyai alokasi yang paling besar secara rata-rata dalam 6 tahun terakhir diikuti dengan Kabupaten Sleman. Kabupaten Bantul mempunyai alokasi belanja modal sangat besar pada tahun 2008 untuk recovery gempa bumi pada tahun 2006. Belanja modal paling kecil dialokasikan dalam APBD Kabupaten Kulonprogo.

Tabel 4. Belanja Modal Kab/Kota di DIY 2006-2011 (dalam juta rupiah)

\begin{tabular}{lrrrrrr}
\hline & \multicolumn{1}{c}{2006} & \multicolumn{1}{c}{2007} & \multicolumn{1}{c}{2008} & \multicolumn{1}{c}{2009} & \multicolumn{1}{c}{2010} & \multicolumn{1}{c}{2011} \\
\hline Kab. Bantul & 91,545 & 95,734 & 297,896 & 123,430 & 123,249 & 90,932 \\
Kab. Gunung Kidul & 102,179 & 108,710 & 132,216 & 98,742 & 47,001 & 143,141 \\
Kab. Kulon Progo & 66,966 & 98,102 & 88,391 & 74,031 & 46,582 & 77,093 \\
Kab. Sleman & 112,395 & 81,308 & 76,069 & 109,127 & 99,812 & 110,782 \\
Kota Yogyakarta & 94,268 & 81,308 & 97,072 & 98,302 & 54,040 & 71,352 \\
\hline
\end{tabular}

Tabel 5. Rasio Belanja Modal terhadap Total Belanja

\begin{tabular}{lc}
\hline Daerah & Persen \\
\hline Kab. Bantul & 9,44 Persen \\
Kab. Gunung Kidul & 10 Persen \\
Kab. Kulon Progo & 15,40 Persen \\
Kab. Sleman & 11,30 Persen \\
Kota Yogyakarta & 10,32 Persen \\
\hline
\end{tabular}

Dalam tabel 4 dapat dilihat, rasio belanja modal terhadap total belanja masih sangat kecil di semua wilayah di DIY. Meskipun Kabupaten Kulonprogo mempunyai kemandirian daerah yang rendah 7 persen tetapi rasio belanja modalnya paling besar mencapai 15,40 persen. Sebaliknya Kota Yogyakarta mempunyai rasio belanja modal 10,32 persen saja meskipun rasio kemandirian daerahnya mencapai 20 persen. 


\section{Uji Akar Unit}

Salah satu konsep yang dipakai untuk mengetahui stasioneritas data adalah melalui uji akar unit (unit root test). Dengan menggunakan uji DF (Dickey-Fuller) dan uji ADF (Augmented Dickey-Fuller), suatu variabel diuji apakah stasioner atau tidak.
Jika hasil yang di dapat dalam pengujian ini belum stasioner maka akan dilanjutkan ke tahap berikutnya yaitu tahap Uji derajat integrasi (Integration Test).

Dari keempat variabel dalam penelitian ini, semuanya sudah stasioner pada aras level.

Tabel 6. Uji Akar Unit

\begin{tabular}{lcc}
\hline Variabel & ADF Test Statistic & Critical Value \\
\hline Belanja Modal (BM) & $-4,055798$ & $-3.5713^{*}$ \\
Kemandirian Daerah (KD) & -3.644145 & $-2,9228^{* *}$ \\
Efisiensi Keuangan Daerah (EFD) & -4.156353 & $-2,5990^{* * *}$ \\
Efektifitas Keuangan Daerah (EFKD) & -3.760780 & \\
\hline \multicolumn{2}{c}{ *1\% critical value ${ }^{* *}$ \% critical value } & ***10\% critical value
\end{tabular}

\section{Estimasi Regresi Data Panel}

Pada tahap ini dilakukan regresi dengan menggunakan common effect, akan tetapi hasilnya tidak langsung diinterpretasikan karena harus melalui uji pemilihan model untuk menentukan metode panel yang paling tepat apakah common, fixed atau random effect (Tabel 7).

\section{Uji Pemilihan Model}

Selanjutnya pengujian dengan menggunakan metode Hausman Test untuk menentukan model antara fixed effect atau random effect (Tabel 8).
Dari perhitungan tersebut, nilai probabilitas pada test cross section random effect memperlihatkan angka 0,9671 yang berarti tidak signifikan pada derajat kepercayaan $95 \%$, maka metode yang dipilih adalah random effect. Selain itu juga dapat dilihat nilai chi square 0.261620 lebih kecil daripada nilai chi square tabel 7,815 maka $\mathrm{HO}$ ditolak sehingga model mengikuti random effect (Tabel 9).

Dari hasil estimasi menggunakan Eviews 7 maka dapat disederhanakan menjadi persamaan sebagai berikut:

\section{$\mathrm{BM}=47,534+22,696 \mathrm{KD}+7,914 \mathrm{EFD}+22,088 \mathrm{EFKD}$ $(2,105) \quad(2,527) \quad(1,841) \quad(1,625)$}

Semua variabel bebas mempunyai koefisien yang positif dan signifikan. Variabel kemandirian daerah (KD) mempunyai pengaruh yang paling besar dengan nilai koefisien 22,696, berikutnya variabel efektivitas keuangan daerah (EFKD) dengan 22,088 dan efisiensi daerah (EFD) dengan nilai 7,914. Besarnya pengaruh variabel EFKD dan KD menunjukan bahwa kemampuan pemerintah daerah dalam meningkatkan PAD dan penerimaan lainnya mempunyai peran yang paling dominan dalam mempengaruhi kemampuan pemerintah daerah untuk belanja modal publik. Naiknya PAD inilah yang dapat digunakan untuk menambah alokasi anggaran belanja modal publik.
Pengujian asumsi klasik dapat dilakukan dengan baik, permasalahan multikolinieritas dapat terselesaikan dalam data panel, artinya data panel dapat menjadi solusi jika data mengalami multikolinieritas. Karena model yang dipakai dalam penelitian ini adalah data panel maka masalah multikolinieritas tersebut dapat diatasi sehingga pengujian multikolinieritas tidak diperlukan lagi. Permasalahan heteroskedastisitas dan autokorelasi dapat diatasi dengan metode GLS (Generalized Least Square) sehingga model tersebut diberi perlakuan white-heteroskedasticity-consistent covariance untuk mengantisipasi data yang tidak homoskedastisitas. Heteroskedastisitas terjadi jika 
nilai $\mathrm{R}^{2}$ regesi panel model cross weighted lebih besar dari $\mathrm{R}^{2}$ regresi awal. Dalam tabel dibawah ini $\mathrm{R}^{2}$ adalah 39 persen. Uji autokorelasi dapat dilakukan dengan melihat nilai DW stat, ketika nilainya mendekati 2 maka terdapat autokorelasi. Berdasarkan estimasi output di atas, nilai DW adalah 2.281201. Nilai tersebut berada pada interval 1,54 dan 2,46 yang artinya tidak mengindikasikan adanya autokorelasi.

Tabel 7. Hasil Regresi Data Panel dengan Common Effect

Dependent Variable: ?BM

Method: Pooled Least Squares

Date: 10/28/12 Time: 05:41

Sample: 20062011

Included observations: 6

Number of cross-sections used: 5

Total panel (balanced) observations: 30

\begin{tabular}{crrrr}
\hline \hline Variable & Coefficient & Std. Error & t-Statistic & Prob. \\
\hline \hline ?KD & 45.20837 & 27.2237 & 1.660664 & 0.1110 \\
?EFD & 2.463427 & 1.11282 & 2.213655 & 0.0343 \\
?EFKD & 10.64796 & 6.80636 & 1.564413 & 0.0932 \\
Fixed Effects & & & & \\
_BTL--C & 1.764047 & & & \\
_GK--C & 0.592824 & & & \\
_KP--C & 0.547549 & & & \\
_SLM--C & 5.232886 & & \\
_YK--C & 6.087652 & & \\
\hline \hline R-squared & 0.302579 & Mean dependent var & 6.364575 \\
Adjusted R-squared & 0.080672 & S.D. dependent var & 2.474130 \\
S.E. of regression & 2.372235 & Sum squared resid & 123.8050 \\
Log likelihood & -63.83081 & F-statistic & 4.772387 \\
Durbin-Watson stat & 2.236207 & Prob(F-statistic) & 0.018987 \\
\hline \hline
\end{tabular}

Tabel 8. Hausman Test

Correlated Random Effects - Hausman Test

Pool: Untitled

Test cross-section and period random effects

\begin{tabular}{|c|c|c|c|}
\hline Test Summary & $\begin{array}{l}\text { Chi-Sq. } \\
\text { Statistic }\end{array}$ & Chi-Sq. d.f. & Prob. \\
\hline Cross-section random & 0.261620 & 3 & 0.9671 \\
\hline Period random & 0.203817 & 3 & 0.9770 \\
\hline $\begin{array}{l}\text { Cross-section and period } \\
\text { random }\end{array}$ & 0.902773 & 3 & 0.8248 \\
\hline
\end{tabular}

Cross-section random effects test comparisons:

\begin{tabular}{crrrr} 
Variable & Fixed & Random & Var(Diff.) & Prob. \\
\hline \hline ?KD & 2.754180 & 0.677906 & 37.817138 & 0.7356 \\
?EFKD & 0.090113 & -0.014676 & 0.043662 & 0.6160 \\
?EFD & -0.144627 & -0.139422 & 0.024059 & 0.9732 \\
\hline \hline
\end{tabular}


Tabel 9. Hasil Regresi Data Panel dengan Random Effect

Dependent Variable: ?BM

Method: GLS (Variance Components)

Date: 10/28/12 Time: 05:42

Sample: 20062011

Included observations: 6

Number of cross-sections used: 5

Total panel (balanced) observations: 30

\begin{tabular}{crrrr}
\hline \hline Variable & Coefficient & Std. Error & t-Statistic & Prob. \\
\hline \hline C & 47.533717 & 22.58389 & 2.104762 & 0.0423 \\
?KD & 22.695638 & 8.980499 & 2.527213 & 0.0371 \\
?EFK & 7.9140112 & 4.297677 & 1.841463 & 0.0723 \\
Random Effects & 22.087761 & 13.59321 & 1.624911 & 0.0956 \\
_BTL--C & 0.755440 & & & \\
_GK--C & 0.254836 & & & \\
_KP--C & 2.169072 & & & \\
_SLM--C & 1.795957 & & & \\
_YK--C & 0.637161 & & \\
\hline \hline R-squared & 0.030556 & Mean dependent var & 6.364575 \\
Adjusted R-squared & 0.081303 & S.D. dependent var & 2.474130 \\
S.E. of regression & 2.572742 & Sum squared resid & 172.0940 \\
Durbin-Watson stat & 1.835849 & & & \\
\hline \hline & & & & \\
Statistics including & & & & \\
Random Effects & & & & \\
\hline \hline R-squared & 0.389129 & Mean dependent var & 6.364575 \\
Adjusted R-squared & 0.549413 & S.D. dependent var & 2.474130 \\
S.E. of regression & 3.079683 & Sum squared resid & 246.5957 \\
Durbin-Watson stat & 2.281201 & & \\
\hline \hline
\end{tabular}

Hasil yang diperoleh dalam persamaan data panel menunjukkan ketiga rasio keuangan daerah menunjukkan hasil yang positif dan signifikan sebagaimana dibahas dalam kajian teori. Akan tetapi hasil $\mathrm{R}^{2}$ menunjukkan hasil yang kecil hanya 0,38 atau 38 persen saja. Artinya kinerja keuangan yang diproksi dari PAD tidak dapat mempengaruhi belanja modal publik.

Konstanta dari persamaan regresi adalah 47,534 artinya apabila ketiga variable independen tidak berubah maka besaran belanja modal adalah Rp47.534.000.000. Variabel kemandirian daerah (KD) mempunyai koefisien 22,696 dengan nilai uji statistic 2,527 yang artinya positif dan signifikan. Kemandirian daerah merupakan kemampuan daerah dalam menghasilkan pendapatan asli daerah secara relatif ter- hadap total pendapatan. Selama ini semua daerah di Indonesia banyak tergantung pada dana DAU. Semakin besar PAD maka kemampuan daerah membelanjakan dalam modal publik juga semakin naik.

Rasio efisiensi menunjukkan koefisien yang positif dan signifikan, artinya semakin efisien daerah maka kemampuan belanja modal menjadi lebih besar. Dengan koefisien 7,914 EFD mempunyai pengaruh yang paling kecil daripada ketiga variabel bebasnya. Dari data deskriptif, semua daerah di DI Yogyakarta belum menunjukkan efisiensi, hal ini dapat dilihat dalam periode penelitian tidak ada satuvpun data yang menunjukkan angka kurang dari 1 , artinya penerimaan lebih besar dari pengeluaran. Semua daerah mempunyai APBD yang defisit. Sedangkan rasio efektivitas menunjukkan angka yang 
Tabel 10. Regresi Belanja Modal terhadap PDRB

Dependent Variable: PDRB

Method: Least Squares

Date: 11/08/12 Time: 10:11

Sample: 130

Included observations: 30

\begin{tabular}{crrrr}
\hline \hline Variable & Coefficient & Std. Error & t-Statistic & Prob. \\
\hline \hline C & 5.815481 & 1.242859 & 4.679115 & 0.0001 \\
BM & 1.918280 & 1.186459 & 1.616811 & 0.0226 \\
\hline \hline
\end{tabular}

baik karena melampaui target penerimaan yang telah ditetapkan. Menurut regresi data panel variable EFKD mempunyai koefisien 22,088 dan nilai t statistic 1,625.

\section{Hubungan PDRB Dan Belanja Modal}

Belanja modal mempengaruhi PDRB secara positif dan signifikan, yaitu konstanta sebesar 5,815 dengan nilai t statistik 4,679 dan koefisien 1,918 dengan nilai t statistik 1,617. Dalam regresi data panel sebelumnya model kinerja daerah yang dinyatakan dalam rasio keuangan daerah tersebut hanya mampu menerangkan perubahan pada variabel PDRB sebesar 35 persen yang ditunjukkan dengan R2 (Tabel 10).

Belanja modal publik mempengaruhi pertumbuhan ekonomi yang diproksi dengan PDRB secara positif dan signifikan, yaitu sebesar 1,918 dan nilai t 1,617. Pengeluaran yang merupakan komponen dalam pendapatan nasional (pendapatan daerah) pasti mempengaruhi PDRB namun koefisiennya cukup kecil mengingat besaran belanja modal setiap daerah masih sangat kecil secara relatif jika dibandingkan dengan total belanjanya apalagi jika dibandingkan dengan PDRBnya. Akan tetapi, belanja modal mempunyai R2 yang sangat tinggi mencapai 89 persen.

\section{SIMPULAN}

1. Semua daerah di Daerah Istimewa Yogyakarta masih mempunyai tingkat kemandirian daerah (KD) yang sangat rendah karena kurang dari 25 persen. Selama kurun waktu 2006-2011 peningkatan PAD hanya kecil sekali tidak sebanding dengan peningkatan pendapatan total, apalagi dibandingkan dengan tingkat belanjanya. Kenaikan pendapatan banyak berasal dari DAU. Kota Yogyakarta mempunyai rasio KD yang cukup sekitar 20 persen sedangkan Kabupaten Kulonprogo hanya bias mencapai 4 persen saja. Dalam persamaan regresi data panel, variable Kemandirian Daerah (KD) mempunyai koefisien positif dan signifikan yaitu 13,715 dan nilai t 1,527 .

2. Sedangkan tingkat efisiensi daerah (EFD) menunjukkan nilai yang kurang baik karena lebih dari satu (>1) artinya daerah di DIY mempunyai APBD yang defisit. Namun, tingkat efisiensi masih memberikan pengaruh yang positif dan signifikan dengan nilai koefisien 6,625 dan nilai t statistic 1,541.

3. Variable efektivitas daerah secara deskriptif menunjukkan rasio yang cukup efektif, karena nilainya secara ratarata lebih dari satu artinya semua daerah di DIY mampu melampaui target penerimaan yang telah ditetapkan. Koefisien yang dihasilkan adalah 22,088 dengan nilai uji t sebesar 1,416. Akan tetapi, efektivitas tersebut dicapai dengan pertumbuhan PAD yang masih kecil. Target yang ditentukan oleh pemerintah daerah tidak menunjukkan kenaikan yang berarti, pemerintah daerah masih belum dapat menggali potensi penerimaan daerah sehingga penentuan target PAD cenderung konservatif dengan pendekatan adaptif yaitu menjadikan PAD tahun sebelumnya sebagai benchmarking. 


\section{DAFTAR PUSTAKA}

Abdullah. S., Halim. A. 2006. Studi atas Belanja Modal pada Anggaran Pemerintah Daerah dalam Hubungannya dengan Belanja Pemeliharaan dan Sumber Pendapatan. Jurnal Akuntansi Pemerintah, 2(2).

Arsyad, L. 2004. Pengantar Perencanaan dan Pembangunan Ekonomi Daerah. Edisi Ketiga. Yogyakarta: BPFE.

Gujarati, D.N. 2003. Basic Econometrics. International Edition. Published by Prentice- Hall International. Inc.

Halim. A. 2001. Manajemen Keuangan Daer$a h$. Yogyakarta: UPP Akademi Manajemen Perusahaan YKPN.
Harianto, D. \& Adi, P.H.. 2007. Bungai Rampai Manajemen Keuangan Daerah. Yogyakarta: UPP-AMP YKPN.

Hirawan, S.B.1986. Analisa tentang keuangan daerah Indonesia. Ekonomidan Keuangan Indonesia, 34(1), 89-119.

Kawedar. 2008. Pendekatan Penganggaran Daerah \& Akuntansi Keuangan Daerah. Jilid 2. Semarang: Undip.

Mardiasmo. 2002. Otonomi dan Manajemen Keuangan Daerah. Yogyakarta: Andi.

Saad, I. 2000. Persiapan desentralisasi dan otonomi daerah.. Jakarta: SMERU

Vegasari, I.K. 2010. Flypaper Effect Pada Dana Alokasi Umum Dan Pendapatan Asli Daerah Terhadap Belanja Daerah Di Pemda Seluruh Indonesia. Jurnal Akuntansi, 6(6) 